\title{
Historical perspectives of The American Association for Thoracic Surgery: Dr David B. Skinner (1935-2003)—a surgeon and something more
}

\author{
Kevin W. Southerland, MD, Thomas A. D'Amico, MD, and The American Association for \\ Thoracic Surgery Centennial Committee
}

David Bernt Skinner (Figure 1), the 77th president of The American Association for Thoracic Surgery (AATS), was born on April 28, 1935, in Joliet, Illinois, and he was raised in Cedar Rapids, Iowa. His educational achievements were remarkable. He attended the University of Rochester, where he attained his BA degree and graduated second in his class with high distinction in 1956. He eventually married the number one student in his class, May Elinor (Ellie) Tischer, who remained his closest friend and advisor throughout his life. They were married for 46 years, and had 4 daughters-Linda, Kristin, Carise, and Margaret.

Following his time in Rochester, New York, he attended Yale University Medical School, where he graduated first in his class and was elected to the Alpha Omega Alpha Honor Society. Dr Skinner completed his general and thoracic surgical training at the Massachusetts General Hospital under the mentorship of Dr Edward D. Churchill (28th AATS President) and Dr Richard H. Sweet (40th AATS President). In 1965, he served as Chief Resident and Teaching Fellow at the Harvard Medical School, where he was known ${ }^{1}$ as the "King of the East."

During his residency, Dr Skinner spent a year as a senior registrar in cardiothoracic surgery at the Frenchay Hospital in Bristol, England, with Mr Ronald Belsey. There he developed his interest in surgical management of esophageal pathology, and he was one of Mr Belsey's most productive and influential trainees. They developed a close relationship, becoming lifelong friends and colleagues, and $\mathrm{Mr}$ Belsey eventually became a permanent guest professor with $\mathrm{Dr}$ Skinner in Chicago, until his retirement. The mentorship and training that Dr Skinner received laid the foundation for what turned out to be a remarkable career in academic surgery.

\section{EARLY ACADEMIC CAREER}

Upon completion of his surgical training in 1965, Dr Skinner served in the United States Air Force, at Brook

\footnotetext{
From the Department of Surgery, Duke University Medical Center, Durham, NC. Disclosures: Authors have nothing to disclose with regard to commercial support. Received for publication April 25, 2015; accepted for publication July 4, 2015; available ahead of print Aug 1, 2015.

Address for reprints: Thomas A. D'Amico, MD, Duke University Medical Center, Box 3496, Duke South, White Zone, Room 3589, Durham, NC 27710 (E-mail: damic001@mc.duke.edu).

J Thorac Cardiovasc Surg 2016;151:1-3

$0022-5223 / \$ 36.00$

Copyright (c) 2016 by The American Association for Thoracic Surgery

http://dx.doi.org/10.1016/j.jtcvs.2015.07.002
}

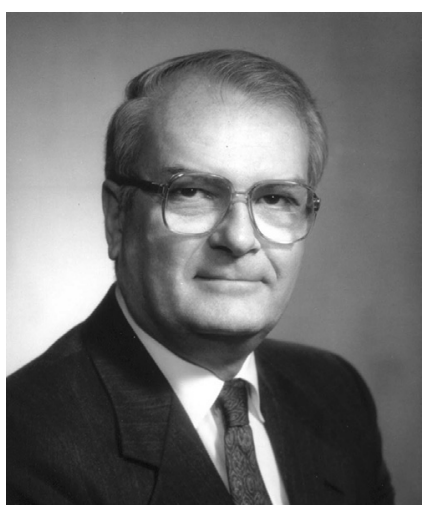

FIGURE 1. David B. Skinner, MD.

Research Hospital in San Antonio, Texas, where he investigated the pathophysiology of esophageal reflux disease. In 1968, he joined the faculty at Johns Hopkins University as an assistant professor, and he was appointed full professor 4 years later. In 1972, he left Johns Hopkins to become the first Dallas B. Phemister Professor and the Chairman of the Department of Surgery at the University of Chicago, in 1972; he was only 37 years old. ${ }^{2}$ The meteoric ascent from assistant professor to chairman is a testament to the talent, leadership, and character of Dr Skinner.

\section{UNIVERSITY OF CHICAGO}

Dr Skinner was chairman at the University of Chicago for 15 years, from 1972 to 1987 . He was charged with the task of restoring the academic and clinical stature of the department of surgery. During his tenure, he established the University of Chicago as one of the premier academic surgical departments in the country. Dr Skinner recruited talented surgeon-scientists in every specialty, dramatically improving academic productivity and funding. In addition to the impressive increase in funding by the National Institutes of Health and the increase in operative volume, the legacy that Dr Skinner left at the University of Chicago was ultimately reflected in the accomplishments of the many medical students, surgical residents, and faculty that he mentored. In fact, 14 of his trainees have become chairs of surgical departments. ${ }^{3}$ Dr Skinner's influence on the evolution of American surgery and the development of academic health care systems will endure through those he trained. 


\section{NEW YORK HOSPITAL-CORNELL MEDICAL CENTER}

In 1987, Dr Skinner left Chicago to become president and chief executive officer of the New York HospitalCornell Medical Center, despite having no formal training in business. In his own words ${ }^{1}$ : "As I leave Chicago to take on a new challenge and to live a new dream in New York-I find that the dream is the same-to create a preeminent center of excellence. Only in New York the complexity of the task will be multiplied by a factor of 10."

Dr Skinner took over at a critical juncture: The hospital was not only in financial trouble but also coping with publicity surrounding the deaths of Libby Zion and Andy Warhol. ${ }^{4}$ Despite these challenges, under Dr Skinner's guidance, the hospital not only recovered but also thrived in many ways. In addition to achieving financial solvency, Dr Skinner presided over the merger of New York Hospital with Columbia Presbyterian Hospital; the merger created the largest academic medical center in the country. He directed the building of the Greenberg Pavilion, a new hospital wing, and oversaw the creation of the New YorkPresbyterian Healthcare System, a network of primary and specialty care centers, which is the largest employer in New York City. ${ }^{1,2}$ Simply put, Dr Skinner was a titan in both the academic surgical community and the American health care arena.

\section{ACADEMIC ACCOMPLISHMENTS}

Dr Skinner was a member of the Institute of Medicine and the National Academy of Sciences. He was named Editor of the Journal of Surgical Research, in 1972, a position he maintained for more than 10 years. During his time on the editorial board, Dr Skinner worked tirelessly to improve the quality of the journal's scientific content. Furthermore, he authored more than 200 peer-reviewed scientific publications and more than 150 book chapters, and he was invited to more than 60 visiting professorships. ${ }^{1}$ Despite his administrative and academic demands, Dr Skinner maintained an active surgical practice, focusing on esophageal disease, and spent a great deal of time teaching his residents.

Although his clinical acumen, technical skills, leadership qualities, and administrative capabilities have been recognized, his commitment to education was second to none, best exemplified by the infamous Saturday morning educational sessions. All residents from his 3 clinical services (vascular, general, and thoracic), as well as all the esophageal fellows and visiting surgeons, participated. Residents presented 2 cases from each service for discussion, which involved interpreting radiographs, discussing surgical approaches, and analyzing any complications. Dr Skinner emphasized adherence to an evidence-based approach to decision making that was well known and appreciated by the residents, but perhaps not by the visitors.

Dr Skinner employed a Socratic technique to engage the residents to prepare to discuss the cases. As soon as a case presentation ended, he would immediately call on someone in the audience to make comments, an inescapable request. Thus, his trainees learned to listen carefully to every presentation, and developed the habits of critical thinking and focusing on discussion points during the presentation so that they would be prepared when called upon for comment. After this session, which typically lasted 2 hours, Dr Skinner and all residents made rounds on every patient on each of the 3 services. Usually the presentations were brief, but the material covered would be enough to discuss among the 50 to 60 patients to occupy an additional 2 hours or more.

Dr Skinner served as president of the Society of University Surgeons, the Society of Surgical Chairmen, and most notably, the AATS. He presided over the 77th meeting of the association in 1997, in Washington DC. In his presidential address, "Shaping the Revolution: Thoracic Surgeons and Something More," Dr Skinner implored thoracic surgeons to take responsibility for the fate of American health care and encouraged the audience to strive for excellence both in and outside of the operating room. As with many endeavors, Dr Skinner was a pioneer in his efforts to reform and improve health care. The manner in which health care is delivered and reimbursed continues to evolve, and the need for surgeons to be involved is greater now than ever; therefore, the theme of Dr Skinner's address is just as applicable today as it was in 1997. As a community, we would be wise to heed his advice": "It is now clear that the cost-based revolution can be controlled by the physicians, who are capable of reducing cost without sacrifice of quality. To achieve this, all of us must be surgeons and something more."

One of his trainees, Dr Mark Ferguson, captured Dr Skinner's leadership style and philosophy on organizational progress ${ }^{2}$ :

Dr Skinner was at his best when differences of opinion about the optimal course of action swirled about. He listened to the opinions of everyone, counseled when asked, and found rare common ground upon which most could agree. Keen observers of this process sometimes had a suspicion that the final outcome was what Dr Skinner had had in mind all along.

Dr Skinner died in New York on January 24, 2003, from a cerebral hemorrhage; he was only 67 years old. On October 19, 2003, his friends, colleagues, and others on whom his influence was great met to honor his achievements in a Festschrift published in the journal ${ }^{2}$ 
he worked so hard to improve, the Journal of Surgical Research; his greatest achievement, it seemed, was the impact he had on others' academic careers. His own career was one of tremendous achievement across the spectrum of an academic surgeon's influence. His impact on patient care will be felt for generations, through both the surgeons that he mentored and trained, and through the systems of health care that he designed and developed. His ultimate legacy will be long lasting-as a surgeon and something more.
The authors are indebted to the counsel and encouragement of Dr Mark Ferguson.

\section{References}

1. Zarins CK. A Tribute to David B. Skinner, MD. Ann Surg. 2003;157-9.

2. Ferguson MK. Festschrift for David B. Skinner, MD. J Surg Res. 2004;117:1-3.

3. Gewertz BL. David Skinner at the University of Chicago. J Surg Res. 2004;117: 4-5.

4. Kelley T Dr. David Skinner, 67; oversaw a hospital merger. The New York Times. January 26, 2003.

5. Skinner DB. Shaping the revolution: thoracic surgeons and something more. $J$ Thorac Cardiovasc Surg. 1997;114:699-706. 